\title{
Interdependence between the Tourism Sector and other Economic Sectors, Applying to Hotels and Restaurants
}

\section{Ezzat Aboelsoud Mohammed}

\author{
Lecturer - The High Institute for Tourism and Hotels, King Mariout, Alexandria, Egypt
}

\begin{abstract}
Tourist industry presents its products at the form of a great tourist service, which consists of transportation, accommodation, feeding, visits and entertainment, (Barakat, 1998). Tourist industry can provides that great service through economic entanglement relationships between organizations which present tourist service and sectors that provide the components that make up this service, (Abd-alwahab, 1998). The number of main and secondary sectors that contribute to the manufacture of the tourist product exceeds 140 sectors, (Alhory and Aldabagh, 2000). Tourist industry depends more on the products of other sectors when they have high quality, suitable price and enough quantity to present tourist industry in a competitive way through the multiple and tourist markets. This study aims at description of the interdependencerelationships for the tourism sectors applying to hotels and restaurants with other economic sectors in the national economy. That's why hotels and restaurants sector is the one which is approved in the economic balance tables in the economic plans in the country. Concerning the economic effects of tourist companies and entertainment places, they can be attributed to
\end{abstract}

money, trade and business sectors, (Tohamy, 2012). This study supposes that interdependence relationships in tourist industry are strong with the local industries. The local industries also are concerned with meeting the needs of the tourism industry. The study was applied by using a randomly sample method on a group of employees in hotel establishments who are responsible for the purchases The study community is represented in the (1:5) star hotels whose number reached twenty hotels in both Cairo and Giza. The number of accepted forms was (18) forms by 90 percent and invalid form were excluded. A number of components were identified through interviews with procurement officials, with 16 components as one of the most reliable components of restaurants and hotels. The study concluded that there are deficiencies in the economic relationships of the tourism industry with the sectors that feed it, as a result of increased dependence on the import component and the leakage of a large amount of tourism income outside the national economy.

Keywords: tourist industry, interdependence relations, economic entanglement; key sector. 


\section{Research Problem}

The problem of the present study could be summarized in the following statements; there is ashortage at economy relations for tourist industry with some other economic sectors. This can lead to increasing in dependence on the imported inputs and losing a lot of economic effects for tourist sector. It also leaks out national economy. Hence, the research had to answer many question:

1. Does tourist industry play an effective role in the development of other sectors in national economy?

2. Is tourist industry, a key sector inside Egyptian economy?

3. Do tourist industries moderate its product through the needs of tourist sector in the acquired description?

4. Does a productive organization for tourist service prefer dependence on local components?

\section{Aims of the study}

The present study aims at identifying inter dependence relations for tourist industry with local productive sectors in Egypt through the following:

1. Studying the economic relations for tourist industry and showing the most obstacles which limit from extra dependence tourism industry on local products.

2. Limiting the reasons for dependence on the imported components at tourism industry.

3. Identifying the interests of local producers to save suitable specifications at products which tourism industry used.

4. Identifying the awareness of people who are responsible for purchase to be interested in dependence on local productions.

\section{Hypothesis of the study}

The current study tests the following hypotheses;

First hypothesis; interdependence relations on tourism industry is strong with local industries.

Second hypothesis; Local industries are aware of the needs of tourism industry.

\section{Limits of the study}

Limits of the study can be divided into:

Place limitations; these limits are found in the (1:5) star hotels in Cairo and Giza. .

\section{Introduction}

The tourism sector is primarily a consumer sector, (Aldabagh, 2000).It has a large economic relations and it can also achieve a large amount of movement and activity in the field of feeding industries economy, (Zytoon, 2002). So, countries are aware of the importance of practice tourist activity.

Many countries proved their abilities to achieve great gains because of their practice for tourist activity. Many countries, in their plans, had great interests in tourism because of their ability to achieve high development rates more than different other industries. In some countries, development rates can relate economy to tourist activity, so the economy can be increased or decreased through tourism, (Al hury, and Aldabaghm, 2000).

Tourism is a complete industry and needs for planning, building, shopping and can interact with other economy sectors. It is a key component in development and attraction of investment to develop main services. It is a strong motivation to develop other sectors. It also plays a positive role in economy (Heody, 2006). 


\section{Study reviews}

Contributions of the tourism can be different for each country in the light of the volume of the economy, and its ability for the needs of tourist industry. It also differs at the level of tourists money, the literature of the study is related to the previous studies concerning the subject of tourism industry and interdependent relations for tourist industry with other industries through handling the following elements:

1) The concept of tourism industry, its characteristics and factors of its success.

2) Economic entanglement through concepts, 1. importance and aims.

3) Economic entanglement relations with feeding industries for tourist industry.

\section{The concept of Tourism Industry:}

Many definitions were put tohandle tourism from economic view. It can be defined as "tourist activities which include accommodation, foods, transportations, travels, as a part of national economy. Italso included travelers who visiting places outside their homes and work",(Al any, 2018).

Ghonema, 1996, defined it as; "that economic activity which is concerned with receiving any hospitality of the comer tourists from their countries and places of theirwork. So, that can be occurred because of enjoyments, relaxation and rest for a period of time at least 24 hours and not more than a year.

\section{Tourist industry includes components:}

1. Movement, it represents the movement of tourists by different transportation.

2. Stability in tourist attraction areas.

3. The economic and social results which reflect on the two previous components. The most important one is tourism, where it can achieve development for 52 other technical industries.Moreover (Tewfik, 2009) defines it as "that special and public organizations which take part in development, production and shopping goods and series to serve the tourists' welfare and needs.

The economic results for tourism were measured by measurement methods which were used in other industries. They were positive for employees, production and income. The advantages of tourism as industry are;

Tourism becomes a part of governmental support. It also deserves funding and budget support.

2. Having a sound framework for scheduling, analyzing and disseminating which has accurate and reliable tourism-related data.

3. A means to achieve the identity for tourist activity in national economy, (Richer and Steiner.2017).

The words of industry can becalled upon; each work related to special skill or a kind of crafts, or arts. Manufacturing or it can be called on systematic productive unites which achieve extra values, (Alroby, 2007).

\section{Characteristics of tourist industry.}

The industry of tourism has some characteristics which are similar to heavy industries as follows, (Abdalhady, 2016).

1. High cost for capitalizing which is found in three main structure and equipment.

2. It sometimes requires high techniques at building and it always requires high techniques of transportation and communication.

3. It can slow rates of destructions of investments. 
4. Relatively high labor intensity that requires special skills.

5. It requires the necessity to follow the rapid change in the tastes and the needs of customersand then the arts of production.

6. Tourist industry is witnessing high rates of monopolistic concentration, most notably the international tourism companies.

\section{Features of tourism industry of national economy.}

Some features of tourism industry of national economy can be existed in the country which practice tourist activity in the following :( Deyodar, 2013).

1. Investing in building the necessary infrastructure and renewing it whenever it is necessary and operating it in a manner that ensure the effective achievement of competitive economic benefit. These investments are very big, especially when there are tourist visits in new or developing areas for centers of population gathering in the country.

2. Investment in building the capacity of the tourist reception through building different tourism organization and licensing other services such as health service in the case of medical tourism and cultural and scientific service in the case of conference tourism........etc.

3. Current employing by actual reception for the comer tourists and providing them with some services which included mixed tourist service and it also needs special comfortable employees and gets a lot of concrete inputs and required service to be produced by other sectors.

The necessary factors for the success of tourism industry:

The industry of tourism can be successful through some factors as follows:

\section{Development of the system of work:}

That development can be shown through organizing the hours of work at day, a limited vacation in the week, a limited vacation in the year, paid legal leave, (Alsesi, 2007). Moreover, the development of income distribution pattern to raise the standard of wages to increase other types of human's needs without the key needs as tourism, (Abdahady, 2016).

\section{Ease of relocation:}

Ease of relocation can be achieved through creating big politic unite among countries. In addition to spreading languages between different countries to broaden the concept (Abd-alhady, 2016).Moreover, the revolution in transportation and communication increased because man likes travelling (Al sesi, 2017).

\section{Providing as strong production base:}

Tourism unites need, when providing their services or even when accommodating, a lot of inputs which are produced by other production sectors as a key concentration to support the tourist activity (Abdelhady, 2016). Ifgoods and service came from other areas out the economy because of their slow price or high quality in their production more than local productions. Then, there would not be development for local industry or for localeconomy.The true tourist development is the economic development is the economic development which is the starter point for it. Because the tourism activity in any country without a prior development of the production sectors leads to the import of most of its requirements and consequently the leakage of a large percentage of the tourism revenue for that country and the burden of the balance ofpayment for that activity instead of relieving debts or achieving positive balance of 
payment accessed

(www.uneptie.org).

\section{The concept of Economic Entanglement:}

Economic entanglement is called by several names, including, structural, industrial and 2 . sectorial entanglements according to its concept (Almashokhy, 2013).The humanity and concrete relation that arise from production process and last between 3 productions unites at the form of special ${ }^{3}$ substitute dependence. These unites represent the first cell for the productive activity. The forms of interdependence can be shown through getting the production requirements such as; materials, services, experiences and also they can be shown through the process of production itself and then through how to distribute the final product. This inter dependence happens at the form of entanglement relations under the prevailing determinants through time and place.

It can also be defined as "permanent complementary relationships that enable two or more institutions to establish structuralties aimed at maximizing mutual benefits from economic social factors and controlling at special environmental variables through opportunities and challenges, (Arab Association for Development, Industry and Mineral2000) It is defined also as inter dependence, interaction between a group of economic components (individuals, groups, activities, sectors, institutions, countries, regions,...etc.) which enter through substitute relations among them,( Algazweny,2004)

\section{The importance of economic entanglement:}

The importance of economic entanglement is through the following points, (Al moshokhy, 1993)
. Economic entanglement plays the role of the engine for cooperation relations among the economic activities. It also achieves the good use of productive energies and raises the competitive ability.

2. The increasing of demanding on the products of economic sectors and then increasing incomes, paying more investments to expand, more employees and raising extra value for sectors.

3. Identifying the extra value for each sector in national economy.

4. Following up and evaluation for the performance of economic sectors, treatment its problems, and the obstacles which achieve strong entanglement with other sectors.

. Identifying key sectors in the national economic which has broad background relations.

\section{Key Sectors at the economic structure:}

Each economy has several sectors with the ability to achieve direct and indirect economic results which are better than other sectors and they are also key sectors at development.

\section{The concept of key-sector:}

There are several definitions for key-sectors one of them is "the sector which has a high rate of front links and back links" (Soofi, 1992). It is also that important sector in development at a developing country and the decision of investments are chosen carefully; (Kweka et al., 2001).It is also defined as; "the sector that can be classified as the highest sector which achieve extra production (Hazari, 2007).

Each industry has front links and back links with other industries.Hershman was the first one who showed these links and development (kweka et al., 2001). These sectors can be classified into: 
1. Sectors have a strong front links; these • industries lead to motivate implementation new investment because of its creation and expansion ofthese products such as the steel industry.

2. Sectors have a strong back links; they are these industries whose creation creates a demand for many of their products. (Al gazweni, 2004) (E.g. Tourism industry). It needs special products such as the sector of agriculture, buildings, repairing, furniture, metal industries, transportation insurance, textiles, energy and printings.

\section{Economic relations for Tourism with other sectors:}

\section{- Economic entanglement between tourism and other agricultural sectors.}

Nearly about 20-25\% (Alsokar, 2009) of tourist payment is for foods and drinks, comes from agricultural products and also more results to activate certain agricultural products. Tourist'sneed these products to come up with the increased quality and quantity for food requirements with increasing and development the local and international movement. Employees need foods in tourist sector whether directly or not. Also, medical tourism based on medicinal plants has emerged.

Then, integration and entanglement between tourism and agricultural sectors are necessary developments which reflectspecial positive results.Three results come from agriculture through productive inputs formany employees at tourism. Moreover, tourism pays more attention to direct or indirect activation for several fast technical products in the light of genetic engineering sciences towardsthe international destination (Al moshokhy, 2013).

\section{Economic entanglement between tourism and industrial sector}

Different kinds of entanglement can achieve through performing tourist institutions frombuilding materials, finishing, equipment, machines, furniture, video, TV and computer sets utility, foods, antiques, jewelry, fabrics.....etc. In addition to the new kinds of tourism such as space and electronic tourism, amusement park and games. These games depend on technological tricks. These technological tricks depend also on the latest invention applications. This can be occurred through industry to show new important dimensions for the future of the relations between tourism and economic sectors, (Almoshokhy, 2013).

The interrelationship between the tourism industry and the economic sector seems to be exist thousands of industrial productive units that depend on tourism in the development of their products.

\section{Economic entanglement between tourism and craft:}

Craft acquires also the concept of industry as it converts the components of production into products and services but at the same time it is moving away from this concept because its products are not subject to the standard of uniformity, or because its output are not subject in most cases to accurate standards. In addition, it depends on manual skill in the conversion process more than on the machine. It isn't subject to limited conditions for the number of employees or the volume of capital or the level of technology or type of machine, but it depends only on the manual skill for the employee. His-Her products reflect culture or technical features traits which express hereditary experiences. Crafts can also be defined as "That industry that depends on the 
mix between manual and mechanic skill in converting the components of production into goods and products. These products and goods aren't sometimes subject to the standards, but craft reflects the manual skills that appear on the final product and makes it good and distinctive in artistic and material dimension, (Specialized National Councils, 2012: 2013).

Moreover, it can be defined as "These productive industries of handicraft goods or plastic arts expressing the civilizational or cultural heritage or arts and social life related to different races. So, they can attract tourists all over the world to demand them, (Hassaneen, 2016). The importance of craft industries appears to make it a tool of great importance in the movement of economic activity and an effective tool to achieve the development through:

1- Its dependence on local resources and materials which are found in their places with suitable prices.

2- Low investment cost for one job opportunity in it compared to other productive sectors.

3- The limited costs required for training, as it relies mainly on the job training, and for its use of uncomplicated technical systems.

- Its ability to develop the country and convert it from just agricultural lands into productive units and exports its productions because of its spread in a lot of rural and urban areas. Moreover, it helps to find new productive communities in remote areas and takes part in population redistribution and solve this problem, (Helwa, 2012). Many countries made crafts an important tool for economy such as India, Italy, and Malaysia. India is one of the leading countries in the small craft sector. This sector presents about $40 \%$ of the total production and also presents about $45 \%$ of industrial exports. This sector also contributes about $35 \%$ of India's total exports. In addition, It represents about $25 \%$ of some advanced countries (e. g. Paris and London), (Specialized National Councils, 2012: 2013).

As for Egypt, previous experiments and experiences proved that some Egyptian crafts products such as the furniture, leather products, Khan al-Khalil products, aluminium, marble, ready-made clothes, carpets and others have a good reputation in many countries of the world. So, it is at the forefront of the products that can be relied upon to increasethe volume of Egyptian exports to the countries of the world in general and the countries that are linked with Egypt by bilateral or regional agreements in particular. Such as the COMESA countries, the G15 countries and some Arab countries, in addition to working to open new outlets for marketing them in USA and European Union countries, (Specialized National Councils, 2012: 2013).

\section{Research methods}

Descriptive Study relies upon desk \& field research

\section{Methods of Data Collection}

Secondary sources; they include studies related to the subject; (e. g. Books, references, scientific research, conferences, Journals and publications...etc.). Primary sources; they can be personal interviews. Distribution of questionnaire forms.

\section{Community and Sample of the study}

The community of the study consists of many mention details 4:5 star hotels in Cairo and Giza governorates. They consisted of (20. N) Hotels. 


\section{Designing questionnaire form}

The questionnaire form was designed on the base of quality and quantity of required data in the light of hypotheses and aims of the study. It was also designed based on a number of items as follow:

First: the percentage of dependence on both local and import components.

Second: causes of dependence on import components.

Third: obstacles of dependence on local components which do not have import substitution.

Fourth: local producers should be aware of other sectors for tourist industry needs.

The research sample: The study was applied to a randomly sample of tourist institutions (Hotel and Restaurants)

The study community is represented in the (45) star hotels whose number reached twenty hotels in both Cairo and Giza. The number of accepted forms was (18) forms by 90 percent and invalid form were excluded.
- Form Analysis: The first Item:

- Determining the dependence ratios on local and imported components used

- A number of components were identified through interviews with procurement officials, with 16 components as one of the most reliable components of restaurants and hotels, and the accreditation rates were as follows:

\section{- Local component dependence ratios:}

Analyzing table (1) shows that the highest averages in relying on local ingredients were in favor of each of ( installation and maintenance - building Materials - Metallic furniture - paper, carton and office tools labor - wooden furniture - health tools furnishings- Food - decorations ) which were on average between 94- 99 percent. The lowest average reliance on local ingredients was for (alcoholic drinks, machinery and heavy equipment, electrical appliances), ranging from 13-18 \% and no electronic software was purchased from local products

Table (1) the views of sample study members about local component dependency ratios

\begin{tabular}{|l|c|c|c|c|}
\hline \multicolumn{1}{|c|}{ Items } & Minimum \% & Maximum \% & Average $\%$ & $\begin{array}{c}\text { Standard } \\
\text { deviation }\end{array}$ \\
\hline Heavy machines and equipment & 0 & 60 & 18.36 & 16.72 \\
\hline Electrical appliances for rooms & 0 & 100 & 30.29 & 28.71 \\
\hline Kitchen equipment & 0 & 90 & 34.69 & 24.76 \\
\hline Restaurant items & 5 & 95 & 57.58 & 24.60 \\
\hline Health tools & 0 & 100 & 94.87 & 17.48 \\
\hline Wooden furniture & 50 & 100 & 96.89 & 9.960 \\
\hline Metal furniture & 35 & 100 & 98.36 & 9.70 \\
\hline Furnishings & 10 & 100 & 94.40 & 17,471 \\
\hline Decorations & 40 & 100 & 91.71 & 10,868 \\
\hline Foodstuffs & 60 & 100 & 92.29 & 6,262 \\
\hline Alcoholic beverages. & 0 & 95 & 13.78 & 18,966 \\
\hline Paper, cardboard, and office tools. & 10 & 100 & 97.04 & 14,551 \\
\hline Electronic software & 0 & 0 & 0 & 0 \\
\hline Labor & 80 & 99 & 97 & 3,529 \\
\hline Building materials and contractors & 80 & 100 & 99.29 & 3,442 \\
\hline installation and maintenance & 90 & 100 & 99.71 & 1,547 \\
\hline
\end{tabular}

Source: preparing by the researcher (interviews -service providers) in the field of tourism and hospitality. 


\section{Dependence ratios on imported components}

Table (2) shows that the highest levels of dependency on the imported components were in the favor of (alcoholic drinks machinery and heavy equipment - electrical appliances for rooms - kitchen utensils - restaurant utensils) with dependency rating from 40-82 percent. On the other hand, the lowest averages were for (installation and maintenance - building materials - Metal furniture - wooden furniture - Labor) averaging from 2-3 percent. The electronic software is fully imported from abroad.

Table (2) the views of sample study members about imported component dependency ratios

\begin{tabular}{|l|c|c|c|c|}
\hline \multicolumn{1}{|c|}{ Items } & Minimum \% & Maximum \% & Average $\%$ & $\begin{array}{c}\text { Standard } \\
\text { deviation }\end{array}$ \\
\hline Heavy machines and equipment & 40 & 100 & 81.64 & 16,729 \\
\hline Electrical appliances for rooms & 0 & 100 & 69,71 & 28,71 \\
\hline Kitchen equipment & 10 & 100 & 65,31 & 24,76 \\
\hline Restaurant items & 5 & 95 & 40,22 & 21,87 \\
\hline Health tools & 0 & 100 & 5,13 & 17,48 \\
\hline Wooden furniture & 0 & 50 & 2,71 & 9,62 \\
\hline Metal furniture & 0 & 65 & 1,64 & 9,70 \\
\hline Furnishings & 0 & 75 & 4,27 & 11,89 \\
\hline Decorations & 0 & 60 & 8,29 & 10,86 \\
\hline Foodstuffs & 0 & 40 & 7,71 & 6,26 \\
\hline Alcoholic beverages. & 0 & 100 & 82,20 & 25,35 \\
\hline Paper, cardboard, and office tools. & 0 & 40 & 7,71 & 6,26 \\
\hline Electronic software & 0 & 0 & 0 & 0 \\
\hline Labor & 1 & 20 & 3,00 & 3,52 \\
\hline Building materials and contractors & 0 & 20 & 71 & 3,44 \\
\hline installation and maintenance & 0 & 10 & 29 & 1.54 \\
\hline
\end{tabular}

Source: preparing by the researcher (interviews - service providers) in the field of tourism and hospitality.

The T.Test was also conducted between reliance on the local component and reliance on the import component as shown in Table 3. The test for all components was at a1\% significance except for Component 4, restaurant items, which was at $5 \%$ significance and was as follows:

Reliance on local ingredients is mainly in the traditional industries of the Egyptian economy. Reliance on imported components is concentrated in the advanced industries with High-tech and high quality, which is higher than some of its local or non-existing ones, such as heavy equipment, electronic software, some electrical appliances, and some types of alcoholic and food beverages.

The average reliance on any local component element is not equal to average reliance on any import component element Table (3) in the T.Test shows the average difference, the standard average error difference, the standard deviation difference for both the local and imported elements, the value of $t$, and the significance of SIG. 
Table (3) Comparing local components with imported components using T-Test

\begin{tabular}{|l|c|c|c|c|c|}
\hline \multicolumn{1}{|c|}{ Items } & $\begin{array}{c}\text { The average } \\
\text { difference }\end{array}$ & $\begin{array}{l}\text { Standard } \\
\text { deviation }\end{array}$ & $\begin{array}{c}\text { Average } \\
\text { standard } \\
\text { error }\end{array}$ & Value of (t) & $\begin{array}{c}\text { Sig. (2- } \\
\text { tailed) }\end{array}$ \\
\hline Heavy machines and equipment & $-63,289$ & 33,445 & 4,988 & $-12,689$ &, 000 \\
\hline Electrical appliances for rooms & $-39,422$ & 57,436 & 8,562 & $-4,604$ &, 000 \\
\hline Kitchen equipment & $-30,622$ & 49,527 & 7,383 & $-4,148$ &, 000 \\
\hline Restaurant items & 17,356 & 45,384 & 6,765 & 2,565 &, 014 \\
\hline Health tools & 89,733 & 34,969 & 5,213 & 17,214 &, 000 \\
\hline Wooden furniture & 94,178 & 34,399 & 2,892 & 32,566 &, 000 \\
\hline Metal furniture & 96,711 & 19,410 & 2,894 & 33,424 &, 000 \\
\hline Furnishings & 90,133 & 26,538 & 3,956 & 22,784 &, 000 \\
\hline Decorations & 83,422 & 21,737 & 3,240 & 25,745 &, 000 \\
\hline Foodstuffs & 84,578 & 12,524 & 1,867 & 45,304 &, 000 \\
\hline Alcoholic beverages. & $-68,422$ & 40,567 & 6,047 & $-11,314$ &, 000 \\
\hline Paper, cardboard, and office tools. & 94,089 & 29,102 & 4,338 & 21,688 &, 000 \\
\hline Electronic software & 0 & 0 & 0 & 0 &, 000 \\
\hline Labor & 94,000 & 7,058 & 1,052 & 89,339 &, 000 \\
\hline Building materials and contractors & 98,578 & 6,884 & 1,026 & 96,064 &, 000 \\
\hline installation and maintenance & 99,422 & 3,093 &, 461 & 21,561 &, 000 \\
\hline
\end{tabular}

Source: preparing by the researcher (interviews - service providers) in the field of tourism and hospitality.

\section{The second Item: Reasons for relying on imported components:}

The views of the sample study are, as shown in Figure 1, these represent the reasons for the preference of imported products over local products Thus, it is considered a form of leakage of tourist income and the figure shows that high quality is the first reason to go for imported products and leave similar local products. Second, the high level of technology and then confidence in imported components comes third, which we might consider a third cause, a consequence at the same time of the two former causes, a fourth one is the availability of the amount, and finally the right price, which increases the tendency of tourism service producers to import products with similar local ones.

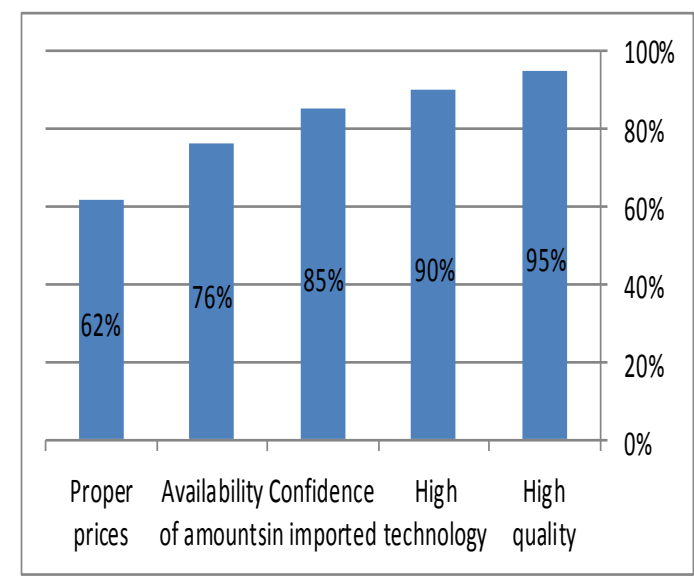

Figure 1, these represent the reasons for the preference of imported products over local products

The views of the sample study on the reasons for increased reliance on the imported components 


\section{Third item: Obstacles to reliance on local components that have an imported alternative}

The obstacles to greater reliance on the local component which were obtained from the study sample has a descending order from the most difficult problems to the least from the perspective of the sample and it was their answers as shown in Figure (2):

1-low levels of technology for machinery and equipment

\section{2- A decline in quality}

3- Not keeping pace with the needs made by the tourism industry.

4- Inaccuracy in Industry

5- Repeated faults on tools and equipment

6- Lack of confidence in the local production of high-tech components

\section{7-Speed of damage}

8- Insufficient quantities of current products

9- Price rise.

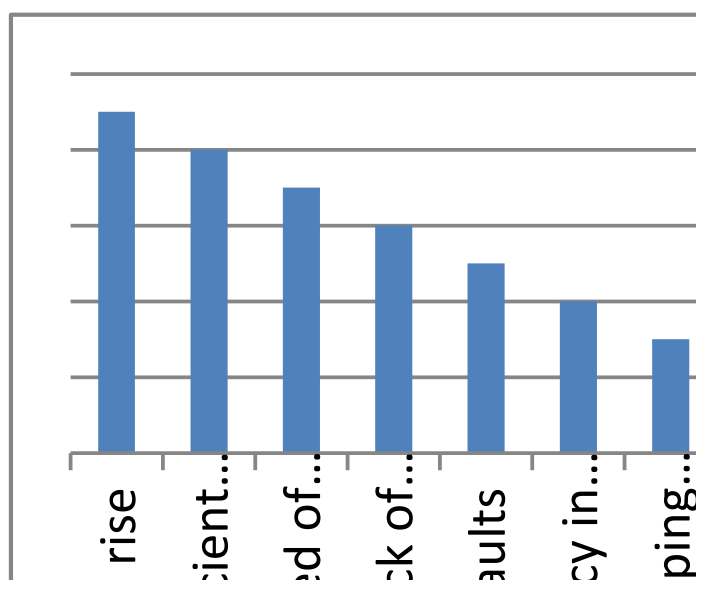

Figure (2) Study sample views on the obstacles to increased dependency on local components.

\section{- The Impact of replacing imported components with similar local components.}

Answers confirmed that replacing imported components with local ones would affect negatively both (the quality of products presented to customers, product price, and order level on the product and the cost of production by $58.5 \%$ of opinions. While it will negatively affect customer product quality by $39.1 \%$ of opinions and will negatively affect production cost by $14.7 \%$ of opinions, this will affect product demand by $12.1 \%$ of opinions, and will affect the product price by $2.4 \%$ of opinions and this is shown in figure (3).

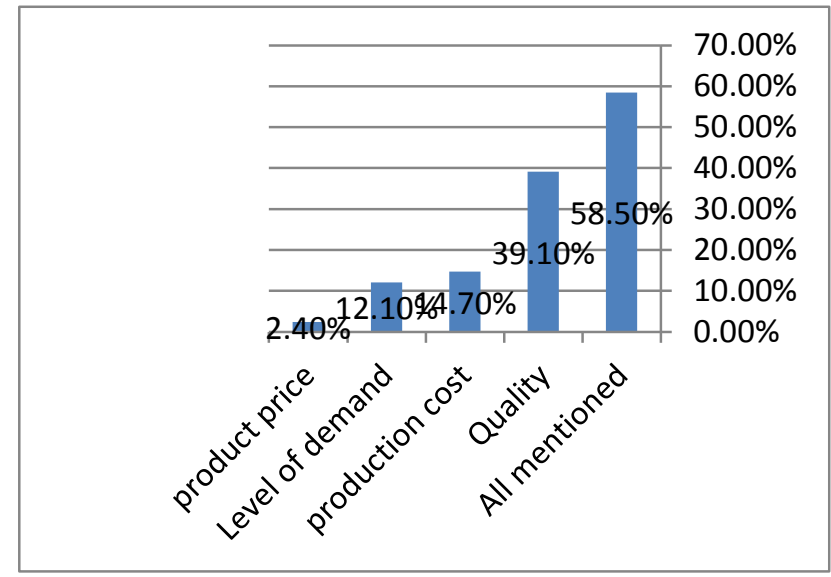

Figure (3) negative impact of replacing imported components with similar local components

\section{- The interest of hotel purchasing management on local products.}

Figure 4 shows that $65.9 \%$ of those responsible for purchases give due care to local products while 34.1 don't pay attention to local products. Which are not a little ratio and demands reconsidering the level of awareness of those who are responsible for tourist industry so as to increase the awareness of the importance of dependency on the local component to reduce to reduce leakage? 
This requires awareness among investors in the production of tourism services that there is a need to focus on local products.

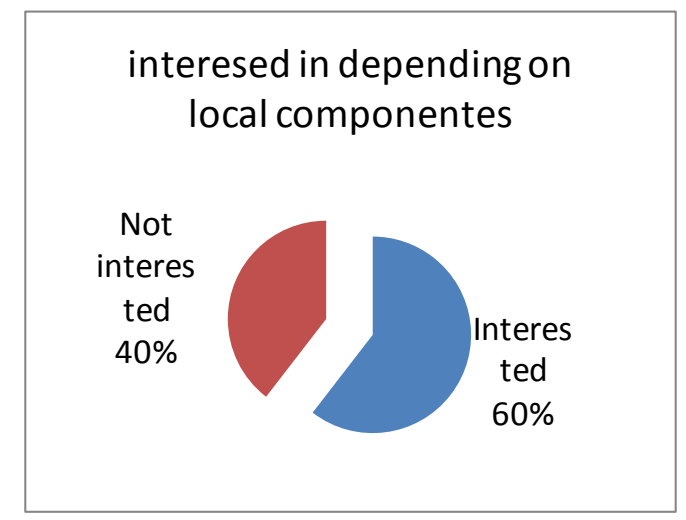

Figure (4) the interest of hotel purchasing management in building on local components

The hotel management company has specified certain specifications for some products that are required to import, although there are local equivalents.

All those responsible for procurement reported that the management company sets specifications for imported products despite the existence of their local equivalents, and it is noted that most departments of Egyptian hotels are foreign administrations of international companies with higher importinclined products.

After discussing of the first, second and third items on the questionnaire there is a weakness in the credit relations of the tourism industry with local industries and much of the demand for tourism industry supplies has leaked outside the national economy and obtained through import from abroad even with an instance produced locally.

Accordingly, the hypothetical theory of the first imposition is rejected which states that the mutual dependence of the tourism industry is strong with local industries, and accepting the alternative theory which states that the relationships of mutual dependence of the tourism industry are weak with local industries.

\section{Item 4: Local producers in other sectors should take into account the needs of the tourism industry}

$68.3 \%$ said that local producers are observing specifications in local components, such as food commodities, furniture, textiles and publications, while $31.7 \%$ denied as shown in Table 4.

Table (4) Consideration by local producers of other sectors of the needs of the tourism industry

\begin{tabular}{|c|l|}
\hline Rate & \multicolumn{1}{|c|}{ Term } \\
\hline $68,3 \%$ & $\begin{array}{l}\text { Local producers take into their } \\
\text { account specifications in local } \\
\text { components }\end{array}$ \\
\hline $31,7 \%$ & $\begin{array}{l}\text { Local producers don't take into their } \\
\text { account specifications in local } \\
\text { components }\end{array}$ \\
\hline
\end{tabular}

- The improvement in the level of some local products imported from abroad the answers indicated that $63.4 \%$ confirmed an improvement in these products while $36.6 \%$ denied this, which means a significant improvement by local producers while more work is needed.

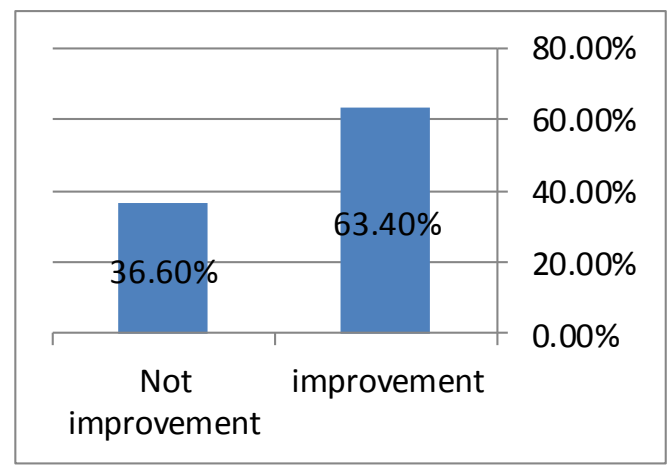

Figure (5) Study sample opinions on improvement of local products 
- The replacement of imported products by tourism service producers with local products. $53.7 \%$ of the study sample indicated that they are replacing some imported products with local ones, which are some of the food products $46.3 \%$ indicated that they insist on relying on the imported components as shown in Figure (6).

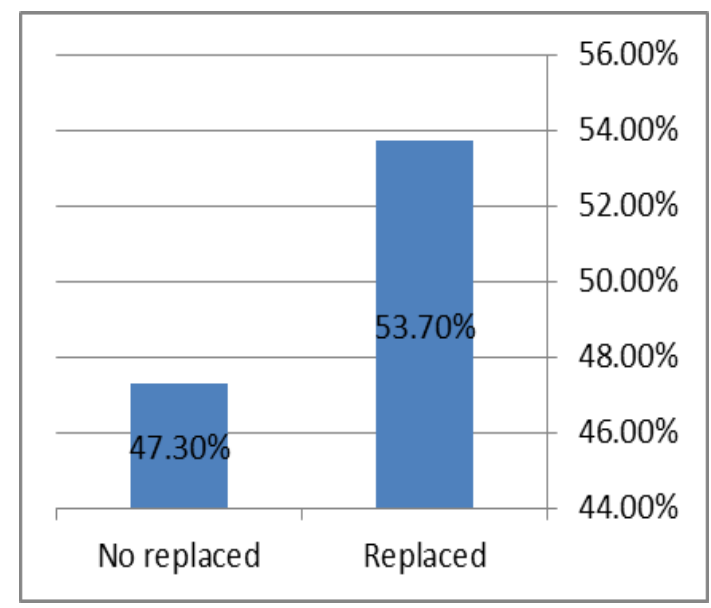

Figure (6) Study sample opinions on replacing imported components with local ones

\section{Best-in-class local components}

The answers to this question came in descending order that determines the best component for those responsible for buying from the highest to the lowest quality and their answers came as follows

The food ingredients come in the first place and are the best of these components ever, the furnishings are in the second place .Then, and third prints are the best component of the local components that are used in the production of tourist services.

Chemicals and detergents are the fourth best local component then comes services of utilities, banks, and technology products in Fifth, sixth and seventh respectively Figure (7) shows the order of the components descending according to their relative weight.

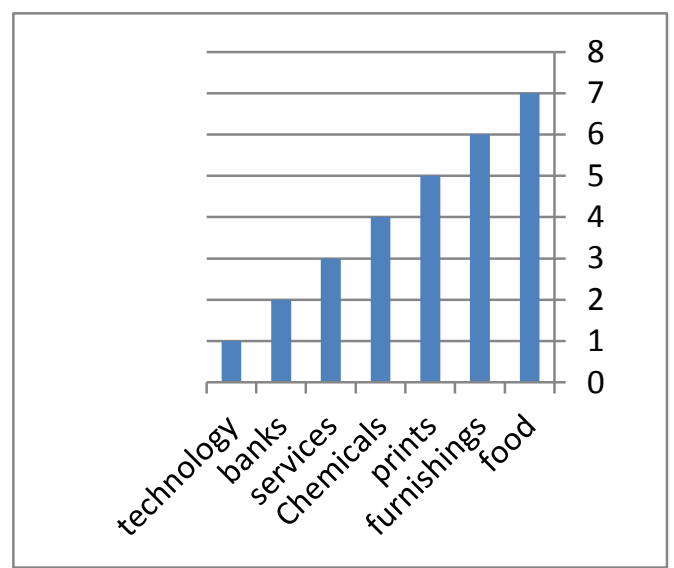

Figure (7) Study sample opinions on the order of the best Local components descending

Out of discussing item 4, it is clear that available local industries are interested in meeting the needs of the tourism industry, although these needs further improvement to include modern and technological industries, not just traditional industries, thus the second hypothesis that local industries meet the needs of the tourism industry is accepted.

\section{Study Results}

1- Tourism contributes to the revitalization of demand and the development of a number of sectors according to The average reliability which are installation and maintenance building materials and Contractors -metal furniture - paper, cardboard and office tools - labor - wooden furniture - health tools furniture - food items - decorations Restaurant utensils - kitchen equipment electrical appliances - machinery and appliances - alcoholic beverages.

2- The tourism sector includes a high amount of import component of direct or total imports, which means that the sector is achieving High relations with the external 
economy.Thus, it represents a burden on the balance of payments rather than contributing to reducing the gap resulting from the continuous deficit that the Egyptian balance suffers from, and most of these components are concentrated in high-tech products according to personal interviews and questionnaire forms.

3- Nevertheless, the tourism sector alone cannot be blamed or accused of failure to fulfill the desired role that the national economy is expecting in the development of its nutritious sectors, owing to:

- It is a sector operating in an economy that is importing, bynature, more than exporting. It also suffers from the weakness of industrial and technological base, the decline in the budget allocated for education and scientific research and the weakness of the competitiveness of Egyptian products due to the poor application of quality systems in industrial products.

- The more traditional industries are, the higher the average reliance on them is the higher technology level of products is, and the greater the trend of reliance on Import Component is.

4- The highest leakage rates of tourist income are achieved in the following components:

- Electronic programs

- Alcoholic drinks

- heavy machinery and equipment

- Electrical devices for rooms

- Kitchen equipment

- Restaurant specific tools

They are expensive investment components taking into account depreciation and regeneration at intervals, causing secondary leakage other than primary leakage when purchased.

5- Quality, high technology, confidence are the distinctive between local and imported products, and increased import tendency, though some of them are produced locally, are the same as those that are at the forefront of local product problems and are obstacles to further relations.

6- Local producers are observing current specifications for products that tourism service providers need by about $68.3 \%$.

7- Local products whose imported counterparts are improving significantly by $63.4 \%$, but do not amount to strong competition with similar imported products.

8- Imported products that are replaced by local products are concentrated in food products, furniture, textiles and publications.

9- Hotel Procurement, in spite of that, gives due care to dependency on local components.

\section{Recommendations}

\section{Recommendations for the tourism industry and its role in the development of other industries}

- Establishing a handling center that sets specifications for tourism products whether goods or services needed for tourism activity. The contract between tourism and food industries is concluded through our methods of handling, namely direct contracting with producers, distributors, exporters and suppliers, which allows producers and service providers to achieve more sales and stimulate demand for and development of these industries.

- Establishing an association for hotel and tourist facilities suppliers and supplying them high-quality local components to supply hotels and tourist facilities so as to stimulate demand for local products and reduce leakage in tourist income.

- Raising awareness among tourism service producers of the importance of relying on local products when identifying purchases in order to reduce direct and indirect leakage 
rates of national tourism income and foreign currencies.

\section{Recommendations for the tourist activity nutritious industries}

1. To examine the product specifications that the tourism industry needs and provide in appropriate quantities, prices and quality to achieve greater economic interrelationship and increase the volume of back-end relationships for the tourism industry.

2. Local producers have conducted a survey of tourism service providers to identify new developments or innovative and nontraditional ways of producing tourism services for their production and to make a gradual shift from direct import to local product dependence.

3. Raising the quality of the current products, Egypt has a good production base, but needs a vigilant and accurate conscience to raise the confidence of the local product, as well as to allow innovation and the implementation of new ideas that often outweigh imported products.

4. Increasing the quality and competitiveness ability of products with imported equivalent in the market and presenting it to tourism service producers to replace imported products with similar local ones.

5. Producing components for hotels in stages such as machines, equipment and appliances.

\section{References}

- Abd-Alwahab, S., (1998). "The role of country and private sector in developing tourist tasks in the light of market economics system, Anniversary book for tourism and hotels, Almaaref Establishment in Alex.

- Abd-Alhady, D., (2016). "Economics of the tourism industry, Alfath for printing and distribution, Alex.

- Alrobi, N., (2007). Tourist planning Establishment of culture University, Alex.
- Alhory, M., \&Dabbagh, I., (2000). "Economics of travel and tourism, Alwaraq Establishment for publishing and distribution, Oman.

- Aldabagh, I., (2001). "Principles of travel and tourism, $1^{\text {st }}$ edition, Alwaraq for printing and publishing, Oman.

- Araqi, M., (2002). "Tourist market research, Faculty of tourism and hotels, Dept. tourist studies, Al-Fayoum University.

- Alani, R., (2018). "Technology of tourist organizing, House of Scientific Knowledge treasure for publishing and distribution, Oman.

- Alsesi, M., (2007). "Principles of tourism, $1^{\text {st }}$ ed, Arab Nile Group, Cairo.

- Alsesi, M., (2017). "Companies of tourism and travel agencies: Scientific domain and applied field, Modern Alwalaa Presses, ShebeenAlkom.

- Almshokhy, H., (2013, Jan). "The development dimensions for international tourism at economic structure: (Analytical study of the activities of tourism revenue in the economies of developing countries) New Afaq Journal, A quarterly scientific journal issued by the faculty of Commerce, Menoufia University; the fifth year, first issue.

- Arab Association for Development, Industry and Mining: "Arab Guide in industrial field, $1^{\text {st }}$ ed, Dec. 2000 .

- Alqazweni, A., (2004). "The national and international economic integration in the light of globalization, first book, theoretical base for economic integration, High Studies Academy, Trables.

- Alsokar, M., (2009). "Tourism, its contents and aims, (1 ${ }^{\text {st }}$ part).

- Barakat, M., (1998). Performance of tourist sector in the light of crises at the period from: 1990: to 1994. Anniversary book for tourism and hotels, Al-maaref Establishment in Alex.

- Debess, Y., (2015). "Tourist attraction, its definition, characteristics, effective factors; A version at Anthropology of tourism, $1^{\text {st }}$ edition, first meeting for creativity and development, Alex.

- Dewedar, M., (2012). "Principles of international politic economy, ( $3^{\text {rd }}$ part) modified print, Alfath for printing and distribution, Alex.

- Ghonema, A., (1996). "Tourism is the way of development for contemporary Egypt, Scientific Arts House, Alex.

- - Hazari, B.R., (2007). "Empirical Identification of key Sectors in the Indian Economy: The 
Review of Economics and Statistics, Vol. 52, pp. 301-305.

- Hassaneen, G., (2012)."Studies at tourist development", Aldar University, Alex.

- Kweka, J., Morrissy, O. and Blake, A., (2001). "Is Tourism akey Sector in TAZANIA? Input Output analysis of Income. Employment and Tax Revenue" http:// www. Nottingham.ac.uk/ttri/pdf/2001-1.pdf. Accessed 29/8/2019.

- Richer, T. \& Steiner, C., (2017). "Sectorial Transformation in Neo - Patrimonial Rentir states 'Tourism Development and state policy in Egypt" November 2017 GiGA Working papers.www.ssrn.com Accessed 18/5/2019.

- - Soofi, A., (1992). "Industry Linkages, Indices of variation and structure of production: an international comparison, Economic systems reach, Vol. 4, No...

- Specialized National Councils: "The Egyptian craft industries: Reality and development requirements", A report of National council for production and economic affairs, twenty -eight session, 2012-2013.

- Tawfiq, M., (2009). "Tourism industry, Zahran House for publishing and distribution, Oman.

- Tohami, S., \&Adrean, S., (2012)."The true impact of tourism sector on Egyptian economy, a paper (N.40) The centre of economic studies.

- UNEP Leakage in Tourism industry http:// www.uneptie.org/pc/tourism/sust_tourism/econ omic.htmAccessed 26/ $7 / 2019$

- Hwedi, M., (2006)."An approach to study tourism, Arab Horizons House, Cairo.

- Helwa A., (2012, Jan)."The uses of the marketing mix at activating crafts, applying to the silk carpet industry at Menoufia governorate, New Afaq Journal.

- Zaytoon, M., (2002). "Tourism and the future of Egypt between development possibilities and risks of wastage, Dar Alshrook for printing and publishing. 